\title{
Protection of Hawks and Owls
}

\author{
L. T. CARMICHAEL
}

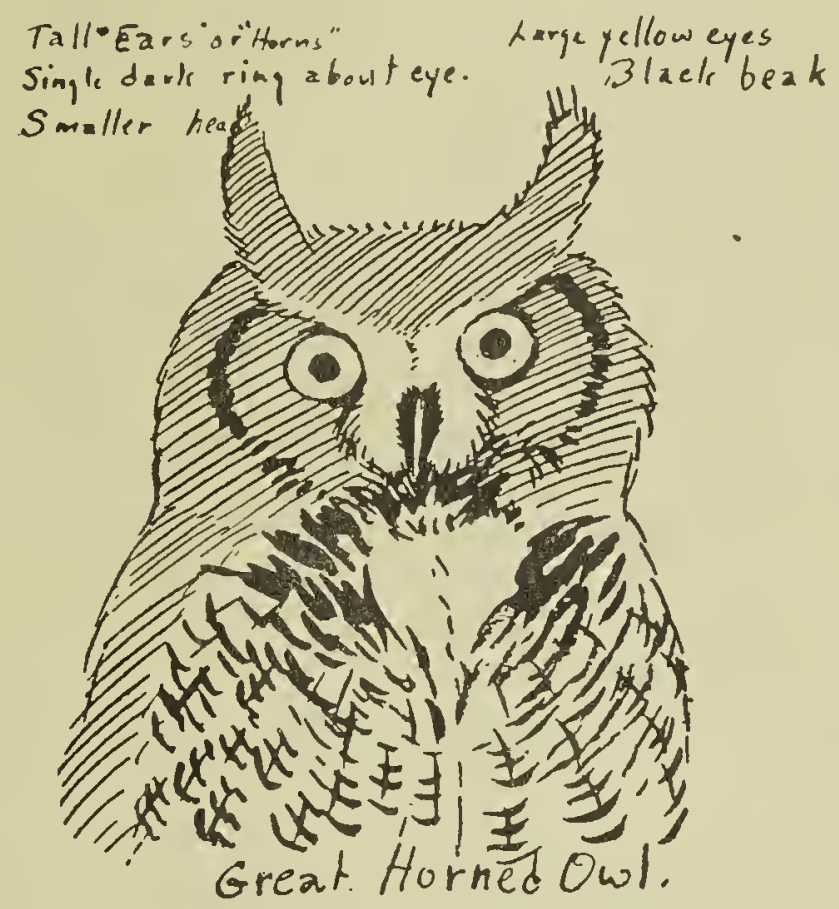

The Blue Jay has received many reports of hawks and owls being shot because of mistaken identity. Recently we received two photographs of two species of hawks shot on the same day, while the hunter was in search for a still more destructive culprit.

In our last issue we asked our readers to be on the look-out for the Great Grey Owl. On March 27, one of these birds was shot at Spirit Lake, Saskatchewan, in mistake for a Horned Owl "that had come to prey on chickens. This happened at dusk, which partly explains the mistake in identity."

In commenting on this incident the Calgary Albertan writes: "What right has man to exterminate other species of God's creatures from the earth? The Passenger Pigeon as a 'race' was completely wiped out, and now the Whooping Crane and the Great Grey Owl are going the same way."

We think it is high time that the Saskatchewan Natural History Society pressed for the introduction of legislation for the protection of all hawks and owls.

It has just been announced by the National Audubon Society that Michigan's hawks and owls won't have to dodge bullets 'any longer. After an intensive state-wide edu- cational campaign by Audubon Societies and sportsmen's clubs, the bill was passed in April with only one dissenting vote in the state legislature.

It is now illegial to kill any kind of hawk or owl in Michigan. An exception provides that farmers may destroy these birds on the rare occassions when they are doing actual damage to domestic stock.

Michigan is the second state to give effective protection to all birds of prey, Connecticut took the same action in 1951.

A spokesman for the Audubon Society writes: "We believe that many other states will soon follow Michigan's good example. The public is beginning to recognize that predators are essential to the health of the wildlife community and that the continued slaughter of hawks, owls, and other predator species is detrimental to the cause of wildlife conservation. The small creatures that hawks and owls eat breed so rapidly that there is an important job for every bird of prey to do."

What is good for Michigan and Connecticut is also good for Saskatchewan. I think there is real merit in such legislation, and that it behooves us to "put the shoulder behind the wheel" and obtain results. 